\title{
Article \\ Phytoextraction of Heavy Metals by Various Vegetable Crops Cultivated on Different Textured Soils Irrigated with City Wastewater
}

\author{
Iftikhar Ahmad $^{1}$, Saeed Ahmad Malik ${ }^{1}$, Shafqat Saeed ${ }^{2}$, Atta-ur Rehman $^{3}$ and Tariq Muhammad Munir ${ }^{4, *,+}$ D \\ 1 Department of Botany, Institute of Pure and Applied Biology, Bahauddin Zakariya University, \\ Multan 60800, Pakistan; rocky_91294@yahoo.com (I.A.); saeedbotany@yahoo.com (S.A.M.) \\ 2 Department of Entomology, Muhammad Nawaz Sharif University of Agriculture, Multan 60500, Pakistan; \\ shafqat.saeed@mnsuam.edu.pk \\ 3 Soil and Water Testing Laboratory, Vehari 60660, Pakistan; aacvehari@gmail.com \\ 4 Department of Geography, University of Calgary, 2500 University Dr. NW, Calgary, AB T2N 1N4, Canada \\ * Correspondence: tmmunir@ucalgary.ca; Tel.: +1-403-971-5693 \\ + Current address: Department of Geography and Planning, University of Saskatchewan, 117 Science Place, \\ Saskatoon, SK S7N 5C8, Canada.
}

check for

updates

Citation: Ahmad, I.; Malik, S.A.; Saeed, S.; Rehman, A.-u.; Munir, T.M. Phytoextraction of Heavy Metals by Various Vegetable Crops Cultivated on Different Textured Soils Irrigated with City Wastewater. Soil Syst. 2021, 5, 35. https://doi.org/10.3390/ soilsystems 5020035

Academic Editors: Matteo Spagnuolo, Paola Adamo and Giovanni Garau

Received: 24 May 2021

Accepted: 17 June 2021

Published: 18 June 2021

Publisher's Note: MDPI stays neutral with regard to jurisdictional claims in published maps and institutional affiliations.

Copyright: (c) 2021 by the authors. Licensee MDPI, Basel, Switzerland. This article is an open access article distributed under the terms and conditions of the Creative Commons Attribution (CC BY) license (https:/ / creativecommons.org/licenses/by/ $4.0 /)$.

\begin{abstract}
A challenging task in urban or suburban agriculture is the sustainability of soil health when utilizing city wastewater, or its dilutes, for growing crops. A two-year field experiment was conducted to evaluate the comparative vegetable transfer factors (VTF) for four effluent-irrigated vegetable crops (brinjal, spinach, cauliflower, and lettuce) grown on six study sites (1 acre each), equally divided into two soil textures (sandy loam and clay loam). Comparisons of the VTF factors showed spinach was a significant and the best phytoextractant, having the highest heavy metal values $(\mathrm{Zn}=20.2, \mathrm{Cu}=12.3, \mathrm{Fe}=17.1, \mathrm{Mn}=30.3, \mathrm{Cd}=6.1, \mathrm{Cr}=7.6, \mathrm{Ni}=9.2$, and $\mathrm{Pb}=6.9)$, followed by cauliflower and brinjal, while lettuce extracted the lowest heavy metal contents (VTF: lettuce: $\mathrm{Zn}=8.9, \mathrm{Cu}=4.2, \mathrm{Fe}=9.6, \mathrm{Mn}=6.6, \mathrm{Cd}=4.7, \mathrm{Cr}=2.9, \mathrm{Ni}=5.5$, and $\mathrm{Pb}=2.5$ ) in response to the main (site and vegetable) or interactive (site * vegetable) effects. We suggest that, while vegetables irrigated with sewage water may extract toxic heavy metals and remediate soil, seriously hazardous/toxic contents in the vegetables may be a significant source of soil and environmental pollution.
\end{abstract}

Keywords: phytoremediation; phytoextraction; heavy metal; wastewater; sewage water; pollution; sustainability; spinach; cauliflower; lettuce

\section{Introduction}

A $1-3{ }^{\circ} \mathrm{C}$ increase in global warming is predicted by the 2050s [1]; the warming in the South Asian region is expected to be higher $\left(2.2-3.3^{\circ} \mathrm{C}\right)[2,3]$, with surface warming as high as $4.2{ }^{\circ} \mathrm{C}$ predicted to be in the northern regions of Pakistan [4] under the RCP8.5 emission scenario. Subsequently, enhanced glacier melts $[5,6]$, soil surface drying, and water table lowering [7] are broadly expected, which may result in an acute shortage of surface- and/or groundwater supply for irrigating crops. Therefore, Pakistan, whose economy is $\sim 21 \%$ agriculture driven, would be one of the regions most severely affected by climate change [6]. Some of these impacts are already being observed. That is why some of the suburban crops are irrigated using dilutes of city wastewater [8,9]. Likewise, approximately 20 million hectares of vegetable or cereal crops grown in a total of 50 countries are also being supplied with substandard waters, including $\sim 80 \%$ untreated or partially treated wastewater of household or industrial nature $[10,11]$ to cope with the issue of food security $[12,13]$. However, given the use of untreated wastewater for growing vegetables or cereal crops for human or animal consumption, human and soil health are at risk.

Wastewaters potentially contain a large variety of pollutants [9], including, but not limited to, unknown chemicals (organic, inorganic or biological nature) and/or salts, metals 
and metalloids, pathogens and hosts, residual drugs and pesticides, endocrine-disrupting chemicals, or active ingredients of human care products. On one hand, these pollutants can impair soil and environmental health [14]; on the other hand, they can be taken up by the growing field crops resulting in buildups of toxic levels of heavy metals in the vegetable biomass. The toxic crops (especially vegetables) when consumed by humans may put their health at risk. Therefore, urban and farming communities' environments and human and animal health are at risk, which indirectly poses an even greater risk of global food security.

A heavy metal is defined as a chemical element of $500 \%$ higher specific gravity than that of normal water [15]. Continuous use of heavy metals containing wastewater for vegetable crop irrigation results in heavy metal accumulation in soil [16] and subsequent transfer to vegetable plants above the safe limits $[17,18]$. The plant accumulation concentration divided by soil accumulation concentration is called the vegetable transfer factor (VTF) [19], which shows the vegetable accumulation rate concerning soil accumulation concentration [20]. The soil-plant transfer of heavy metals is largely dependent on the plant species and is evaluated using the soil-plant TF [21]. The transfer factor is further controlled by several factors: plant age and species, crop variety, heavy metal concentration and its physical and chemical properties, and duration of effect [22].

$\mathrm{Cd}$ toxicity, even at low levels, has been attributed to its bioaccumulation and long half-life of $\sim 30$ years $[8,23,24]$. Cd also is known for its high mobility across the soil-waterplant-environment continuum [25]. A few major toxic plant effects include, but are not limited to, leaf chlorosis, stunted growth, and limited uptake of essential nutrients and protein synthesis [24,26]. Cr toxicity also reduces crop yield via impaired leaf and root hair growth, reduced enzymatic dynamics, and mutagenesis [27]. Toxic soil-water-plant concentrations are reported to impair overall plant growth and reproduction [28]. Excessive amounts of soil $\mathrm{Zn}$ together with soil $\mathrm{Cu}$ may decrease overall plant growth but increase $\mathrm{TF}$, and ingestion of these higher TF vegetables result in acute depression symptoms in humans [29]. Excess levels of $\mathrm{Cu}$ alone in human blood showed acute stomachache and subsequent liver damage in many patients [30].

While the accumulation of heavy metals by wastewater-irrigated crops has been studied over several soil types, these investigations were made using one crop and one soil type at a time. Thus, various crops have not been compared for their comparative VTFs using the same or different soil types. Phytoremediation of the contaminated soils irrigated with wastewaters is an environmentally friendly and green technique [31,32] to remediate the soil-water-air continuum and quantify the translocation of these heavy metals by calculating the VTF.

Thus, an evaluation of the comparative phytoextraction efficiencies of various crops grown on the same and different soil types and irrigated with several wastewater types, or comparison of the VTFs, remained largely unexplored in Pakistan. Therefore, our unique study aims at identifying and assessing the potential sources of contamination to the soil, water, or plant, and evaluating the comparative VTFs of various crops grown on the same and different textured soils irrigated with a variety of wastewaters. The conclusions of this study will be helpful to suggest the necessary mitigation measures and inform policy development.

We hypothesize that the comparative VTF evaluation of various crops grown on the same or different textured soils irrigated with a variety of wastewaters will differ. Therefore, the present study was carried out to quantify the heavy metal $(\mathrm{Zn}, \mathrm{Cu}, \mathrm{Mn}, \mathrm{Fe}, \mathrm{Cd}, \mathrm{Cr}, \mathrm{Ni}$, and $\mathrm{Pb}$ ) accumulation in four vegetables (spinach, brinjal, lettuce, and cauliflower) grown on the same and different soil types irrigated with different wastewaters, and to evaluate the suitability of the wastewater used for growing these vegetables.

The specific objectives of the present study are (1) to quantify the contents of heavy metals in two different soil types and their irrigation wastewater samples, both collected from six different study sites of the Multan suburban area; and (2) to monitor the comparative accumulation of heavy metals between the edible portions of the vegetables grown on the same and different textured soils irrigated with wastewaters, by quantifying 
the vegetable transfer factor. The VTF will also be related to the soil concentrations of heavy metals.

\section{Materials and Methods}

\subsection{Study Sites}

To determine the vegetable transfer factors (VTF) in the effluent-irrigated vegetable crops, a total of six study sites were chosen in the vicinity of the WASA disposal stations within the suburban area of Multan city. The sites had several open and covered drainage channels that fed the vegetable crops. Each site was around one acre in size. We divided the sites (6) into two major soil texture types: sandy loam (3) and clay loam (3). Each of the texture types was irrigated with three types of water: normal, waste (sewage), and normal + waste. The brinjal (Solanum melogena L.) and spinach (Spinacia oleacea L.) crops were sown during January 2016 on a quarter of each site, randomly, while the cauliflower (Brassica oleracea L.) and lettuce (Lactuca sativa L.) were also sown on the rest of the quarters of each site during September 2015. Details of the study sites, their textural classes, the irrigation water types, and the heavy metal concentrations of soil and irrigation waters are shown in Table 1.

Table 1. Chemistry (EC and $\mathrm{pH}$ ) and concentrations of the heavy metals in the study soils and their irrigation wastewaters, sampled during 2015-2016 from six major vegetable production areas in the Multan region of Pakistan + .

\begin{tabular}{|c|c|c|c|c|c|c|c|c|c|c|c|}
\hline \multirow{2}{*}{$\begin{array}{l}\text { Study Site } \\
\text { Soil/Water }\end{array}$} & \multirow[t]{2}{*}{ Soil Texture/Water } & \multicolumn{2}{|c|}{ Chemistry } & \multicolumn{8}{|c|}{ Heavy Metal Concentration $\left(\mathrm{mg} \mathrm{kg}^{-1}\right)$} \\
\hline & & $\begin{array}{c}\mathrm{EC}_{\mathrm{s}} / \mathrm{EC}_{\mathrm{iw}} \\
\left(\mathrm{dSm}^{-1}\right)\end{array}$ & $\mathrm{pH}_{\mathrm{s}} / \mathrm{pH} \mathrm{H}_{\mathrm{iw}}$ & Zn & $\mathrm{Cu}$ & $\mathrm{Fe}$ & Mn & $\mathrm{Cd}$ & $\mathrm{Cr}$ & $\mathrm{Ni}$ & $\mathrm{Pb}$ \\
\hline \multicolumn{12}{|l|}{ Khan village } \\
\hline Soil & Sandy loam & 1.4 & 8.3 & 1.80 & 0.94 & 6.80 & 2.90 & 0.66 & 1.10 & 0.42 & 1.40 \\
\hline Water & Normal & 0.3 & 7.2 & 0.03 & 0.04 & 0.03 & 0.06 & 0.02 & - & - & 0.02 \\
\hline \multicolumn{12}{|l|}{ Vehari road } \\
\hline Soil & Clay loam & 1.5 & 8.4 & 1.66 & 1.28 & 9.64 & 3.68 & 1.40 & 1.62 & 0.46 & 1.74 \\
\hline Water & Normal & 0.3 & 7.1 & 0.04 & 0.03 & 0.09 & 0.02 & 0.02 & 0.02 & - & - \\
\hline \multicolumn{12}{|l|}{ Shujabad road } \\
\hline Soil & Sandy loam & 3.1 & 8.4 & 2.48 & 1.70 & 12.60 & 3.38 & 4.30 & 2.60 & 1.04 & 2.66 \\
\hline Water & Sewage & 2.8 & 6.9 & 0.06 & 0.14 & 0.31 & 0.11 & 0.04 & 0.09 & 0.06 & 0.06 \\
\hline \multicolumn{12}{|c|}{ Industrial estate } \\
\hline Soil & Clay loam & 3.9 & 8.4 & 3.90 & 2.58 & 17.34 & 4.04 & 4.76 & 4.36 & 1.72 & 3.38 \\
\hline Water & Sewage & 3.6 & 6.8 & 0.10 & 0.11 & 0.34 & 0.19 & 0.06 & 0.08 & 0.09 & 0.11 \\
\hline \multicolumn{12}{|l|}{ Suraj miani } \\
\hline Soil & Sandy loam & 2.7 & 8.3 & 2.12 & 2.04 & 11.66 & 3.36 & 2.28 & 3.98 & 1.34 & 2.60 \\
\hline Water & Normal + Sewage & 2.0 & 7.1 & 0.05 & 0.04 & 0.18 & 0.16 & 0.04 & 0.02 & 0.05 & 0.08 \\
\hline \multicolumn{12}{|l|}{ Sameeja abad } \\
\hline Soil & Clay loam & 3.5 & 8.2 & 1.82 & 0.48 & 7.52 & 2.30 & 1.94 & 1.72 & 0.46 & 1.28 \\
\hline Water & Normal + Sewage & 2.1 & 7.1 & 0.40 & 0.08 & 0.07 & 0.14 & 0.07 & 0.40 & 0.07 & 0.05 \\
\hline UNESCAP * & & - & 6.1 & 5.00 & 1.00 & 2.00 & 1.50 & 0.10 & 1.00 & 1.00 & 0.50 \\
\hline Pescod, MD ** & & - & & 2.00 & 0.20 & 5.00 & 0.20 & 0.01 & 0.01 & 0.20 & 5.00 \\
\hline
\end{tabular}

† Each value is a mean of four sample months. * Permissible limits for liquid municipal and industrial effluents in Pakistan. ${ }^{* *}$ Threshold levels of trace elements in irrigation water. ECs and pHs, and ECiw and pHiw denote electrical conductivity and $\mathrm{pH}$ of the soil and irrigation water, respectively. After four months, the study sites (soils) were significantly different in chemistry and heavy metal concentrations (ECs: $p=0.001$; pHs: $p<0.001$; Zn: 0.036; Cu: $p=0.002$; Fe: $p<0.001$; Mn: $p<0.001$; Cd: $p=0.006$; Cr: $p=0.003$; Ni: $p=0.005 ; \mathrm{Pb}: p<0.001$ ). The variable buildup of concentrations that was observed may be due to sewage water irrigation during the experimental period. All respective irrigation waters were also significantly different except for Cr (ECs: $p=0.019 ; \mathrm{pHs:} p<0.001 ; \mathrm{Zn}: 0.031 ; \mathrm{Cu}: p=0.005 ; \mathrm{Fe}: p=0.012$; Mn: $p=0.003 ; \mathrm{Cd}: p=0.004 ; \mathrm{Cr}: p=0.058 ; \mathrm{Ni}: p=0.002 ; \mathrm{Pb}: p=0.013)$.

\subsection{Sampling and Analysis}

A total of 4 composite surface soil $(0-20 \mathrm{~cm})$ samples were randomly collected monthly from each of the six sites receiving wastewater regularly for irrigation, (4 samples * 6 sites * 4 months $=96$ samples). However, the soil samples from the brinjal and spinach crop sites were collected during January-April 2015, compared to the cauliflower and lettuce crop site soil samples collected during September-December 2016. The soil samples were 
air-dried, crushed and sieved to $<2 \mathrm{~mm}$, and stored at room temperature before analyses of the physicochemical properties and heavy metal concentrations. Soil samples were analyzed for textural class, saturation paste electrical conductivity (ECs), and saturation paste $\mathrm{pH}(\mathrm{pHs})$ following methods described by the US Salinity Laboratory Staff following Richards [33]. Textural class of only the first batch (month) of soil samples was analyzed. To quantify the water-soluble soil $\mathrm{Zn}, \mathrm{Cu}, \mathrm{Fe}, \mathrm{Mn}, \mathrm{Cd}, \mathrm{Cr}, \mathrm{Ni}$, and $\mathrm{Pb}$ concentrations, $10 \mathrm{~g}$ of dry soil was extracted with $50 \mathrm{~mL}$ deionized water following Zia et al. [34].

Irrigation wastewater samples were also collected monthly during the soil sampling campaigns. Four replicate polyethylene bottles (acid washed) of $500 \mathrm{~mL}$ each were filled with wastewater one by one at an interval of $10 \mathrm{~s}$ from an open channel flowing to the study site, for all sites. Each of the collected wastewater samples was acidified immediately with $1 \mathrm{~mL}$ of concentrated $\mathrm{HCl}$ to avoid microbial degradation of the heavy metals. The samples were placed in a cooler and transported to a soil- and water-testing laboratory in Multan. Within a week, $50 \mathrm{~mL}$ of the sample was digested with $10 \mathrm{~mL}$ of concentrated $\mathrm{HNO}_{3}$ at $80^{\circ} \mathrm{C}$ until the solution turned clear [35]. The clear solution was then filtered through a Whatman ${ }^{\mathrm{TM}} 42$ filter, diluted back to $50 \mathrm{~mL}$ using distilled water, and stored for analysis.

Edible parts of the harvested vegetables were thoroughly washed sequentially with $1 \% \mathrm{HCl}$ and deionized water (to clean/remove any dust material), air-dried in shade for $24 \mathrm{~h}$, and then oven-dried at $70^{\circ} \mathrm{C}$ until a constant weight. The dried matter was ground to a powder form and then sieved to $<1 \mathrm{~mm}$. One gram of the powder was digested with a mixture of $\mathrm{HNO}_{3}$ and $\mathrm{HClO}_{4}$ in a 2:1 ratio, respectively. The clear digest was filtered and diluted to $50 \mathrm{~mL}$ using deionized water and stored for analysis.

Plant total and soil and wastewater soluble $\mathrm{Zn}, \mathrm{Cu}, \mathrm{Fe}, \mathrm{Mn}, \mathrm{Cd}, \mathrm{Cr}, \mathrm{Ni}$, and $\mathrm{Pb}$ concentrations were measured from the stored extracts using an Atomic Absorption Spectrophotometer (Model AAS Vario 6, Analytik Jena AG, Jena, Germany).

Transfer factors of the vegetables were calculated by dividing the vegetable total heavy metal concentration with the soil water-soluble heavy metal concentration [20], to interpret comparative bioaccumulation of heavy metals by the experimental vegetables grown on the same or different textures soils irrigated with various wastewater sources in Multan.

\subsection{Statistical Analyses}

All data analyses were performed using the SPSS 26.0 package (SPSS, Chicago, IL, USA). A two-way (soil/water and vegetable) multivariate ( $\mathrm{Zn}, \mathrm{Cu}, \mathrm{Fe}, \mathrm{Mn}, \mathrm{Cd}, \mathrm{Cr}, \mathrm{Ni}$, and $\mathrm{Pb}$ ) ANOVA for quantifying the individual and interactive effects of the soil/water and vegetable factors on the response variables of the $\mathrm{Zn}, \mathrm{Cu}, \mathrm{Fe}, \mathrm{Mn}, \mathrm{Cd}, \mathrm{Cr}, \mathrm{Ni}$, and $\mathrm{Pb}$ concentrations in vegetables. Regressions and correlations were also performed where needed. Data were not normally distributed; therefore, they were normalized to $\log 10$ values. Differences were significant when $p<0.05$.

\section{Results}

The ECs of the Industrial estate was the highest $\left(3.9 \mathrm{dSm}^{-1}\right.$; Table 1) and was significantly higher than those of the Khan Village $\left(1.4 \mathrm{dSm}^{-1}\right)$ and Vehari road $\left(1.5 \mathrm{dSm}^{-1}\right.$; $p=0.001, p=0.019$, respectively) sites, in which the two sites had significantly lower ECs than the Sameej abad site $\left(3.5 \mathrm{dSm}^{-1} ; p=0.016\right)$. All other ECs comparisons did not significantly differ. The $\mathrm{pHs}$ of the sites were not significantly different, except for the Industrial estate $\mathrm{pHs}$ (8.4; Table 1), which was significantly higher than that of the Sameeja abad site $(8.2 ; p=0.005)$.

The ECiw of Industrial estate was also the highest $\left(3.6 \mathrm{dSm}^{-1}\right.$; Table 1$)$ and was significantly higher than those of the Khan Village $\left(0.3 \mathrm{dSm}^{-1}\right)$ and Vehari road $\left(0.3 \mathrm{dSm}^{-1}\right.$; $p=0.001, p=0.017$, respectively) sites, in which the two sites had significantly lower ECiw than the Shujabad site $\left(2.8 \mathrm{dSm}^{-1} ; p=0.017\right)$. All other comparisons did not significantly differ. The pHiw of the sites were not significantly different with the exceptions of the Khan Village pHiw (7.2; Table 1), which was significantly higher than those of the Industrial 
estate $(6.8 ; p=0.001)$ and Shujabad $(6.9 ; p=0.017)$ where the Shujabad site had significantly lower pHiw than that of the Soraj miani site $(7.1 ; p=0.017)$.

Overall, the study sites (soils) were significantly different in chemistry and heavy metal concentration (Table 1; ECs: $p=0.001$; pHs: $p<0.001$; Zn: 0.036; Cu: $p=0.002$; Fe: $p<0.001$; Mn: $p<0.001$; Cd: $p=0.006$; $\mathrm{Cr}: p=0.003$; Ni: $p=0.005$; and Pb: $p<0.001)$. All respective irrigation waters were also significantly different, except for Cr (ECs: $p=0.019$; pHs: $p<0.001 ; \mathrm{Zn}: 0.031$; Cu: $p=0.005 ; \mathrm{Fe}: p=0.012 ; \mathrm{Mn}: p=0.003$; Cd: $p=0.004$; Cr: $p=0.058$; Ni: $p=0.002$; and $\mathrm{Pb}: p=0.013$ ). It is to be noted that Mn is not exactly a heavy metal but toxic when absorbed or present in excessive amounts.

Soil heavy metal concentrations were significantly different $(p<0.05$; Table 1$)$ between sites with the highest concentrations of all metals at the Industrial estate $(\mathrm{Zn}=3.9, \mathrm{Cu}=2.6$, $\mathrm{Fe}=17.3, \mathrm{Mn}=4.0, \mathrm{Cd}=4.8 . \mathrm{Cr}=4.4, \mathrm{Ni}=1.7$, and $\left.\mathrm{Pb}=3.4 \mathrm{mg} \mathrm{kg}^{-1}\right)$, and the lowest at the Khan Village site $(\mathrm{Zn}=1.8, \mathrm{Cu}=0.9, \mathrm{Fe}=6.8, \mathrm{Mn}=2.9, \mathrm{Cd}=0.7, \mathrm{Cr}=1.1, \mathrm{Ni}=0.4$, and $\mathrm{Pb}=1.4 \mathrm{mg} \mathrm{kg}^{-1}$ ). All other sites had a mix of higher or lower concentrations of the heavy metals compared to each other.

There were significant $(p<0.05)$ main (site/water and vegetable) and interactive (soil/water * vegetation) effects on phytoextraction of all metal concentrations. At the site level, the $\mathrm{Cu}, \mathrm{Mn}, \mathrm{Cd}$, and Ni phytoextraction values were significantly different, except for the $\mathrm{Cu}$ and $\mathrm{Cd}$ values at Khan Village that did not differ from the corresponding values at Shujabad road and Vehari road (both; $p=1.000, p=0.073$, respectively; Figures 1 and 2), $\mathrm{Cd}$ concentrations at Sameeja abad did not differ from those at the Khan village and Vehari road values (both $p=1.00$, respectively Figures 3 and 4 ). The phytoextraction concentrations of $\mathrm{Mn}, \mathrm{Cd}$, and Ni also significantly differed between all four vegetables; however, the lettuce $\mathrm{Zn}$ concentration did not differ from that in brinjal $(p=1.00)$, the cauliflower $\mathrm{Cu}$ value did not differ from that in spinach (0.189), and the lettuce and cauliflower values did not differ from those in brinjal and spinach (both; $p=1.00$; Figures 1 and 2)

There were significant $(p<0.05)$ main (site and vegetable) and interactive (soil * vegetation) effects on vegetable transfer factor (VTF) for all metals, except no site/water * vegetable interaction for the Cr VTF was found ( $p=0.585$; Tables 2 and 3$)$. VTF comparisons revealed that spinach was the best phytoextractant with the highest phytoextraction values (spinach: $\mathrm{Zn}=20.2( \pm 3.6), \mathrm{Cu}=12.3( \pm 8.3), \mathrm{Fe}=17.1( \pm 8.1), \mathrm{Mn}=30.3( \pm 16.5), \mathrm{Cd}=6.1$ ( \pm 4.5$), \mathrm{Cr}=7.6( \pm 5.7), \mathrm{Ni}=9.2( \pm 3.1)$, and $\mathrm{Pb}=6.9( \pm 1.7)$-Tables 2 and 3$)$ followed by cauliflower and brinjal, while lettuce had the lowest VTF values for phytoextraction (lettuce: $\mathrm{Zn}=20.2( \pm 4.3), \mathrm{Cu}=12.3( \pm 4.0), \mathrm{Fe}=17.1( \pm 2.0), \mathrm{Mn}=30.3( \pm 2.4), \mathrm{Cd}=6.1$ ( \pm 4.7$), \mathrm{Cr}=7.6( \pm 5.1), \mathrm{Ni}=9.2( \pm 2.6)$, and $\mathrm{Pb}=6.9( \pm 1.3)$-Tables 2 and 3$)$ under main (site and vegetable) or interactive (site ${ }^{*}$ vegetable) effects. Values in brackets show the standard deviation.

The soil metal concentration-VTF correlations were significant $(p<0.05$; Figures 3 and 4$)$ for brinjal and lettuce for $\mathrm{Zn}$; for brinjal and cauliflower for $\mathrm{Cu}$; for brinjal only for $\mathrm{Fe}$; all for $\mathrm{Mn}$ and $\mathrm{Ni}$; for spinach for $\mathrm{Cd}$ and $\mathrm{Cr}$; and for brinjal, lettuce, and spinach for $\mathrm{Pb}$ (Figures 3 and 4). 


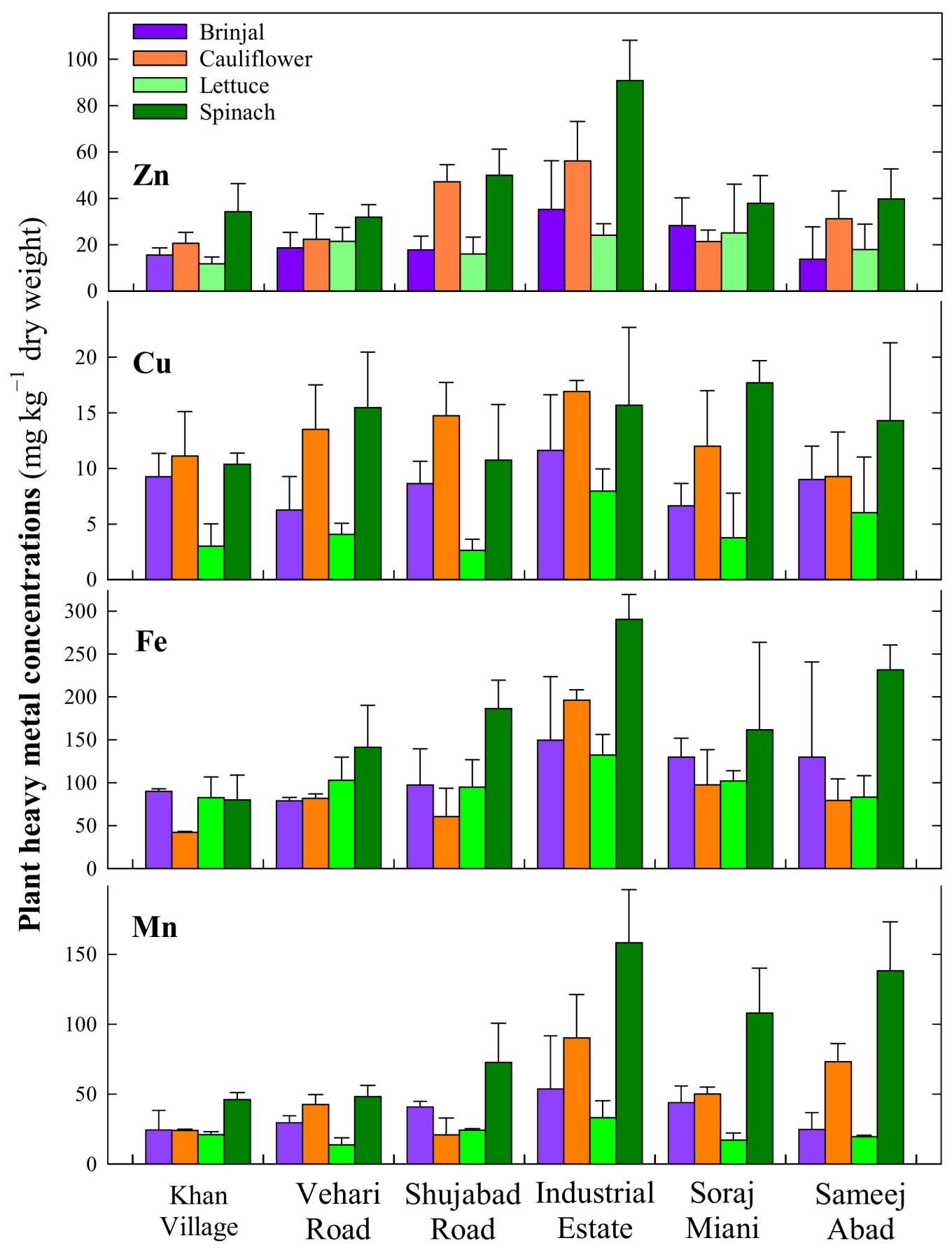

Figure 1. $\mathrm{Zn}, \mathrm{Cu}, \mathrm{Fe}$, and $\mathrm{Mn}$ concentrations ( $\mathrm{mg} \mathrm{kg}^{-1}$ dry weight) in brinjal (Solanum melogena) and spinach (Spinacia oleacea) harvested in April 2016, and lettuce (Lactuca sativa L.) and cauliflower (Brassica oleracea) harvested in December 2015 from the Khan Village, Vehari road, Shujabad road, Industrial estate, Soraj miani, and Sameej abad study sites. 


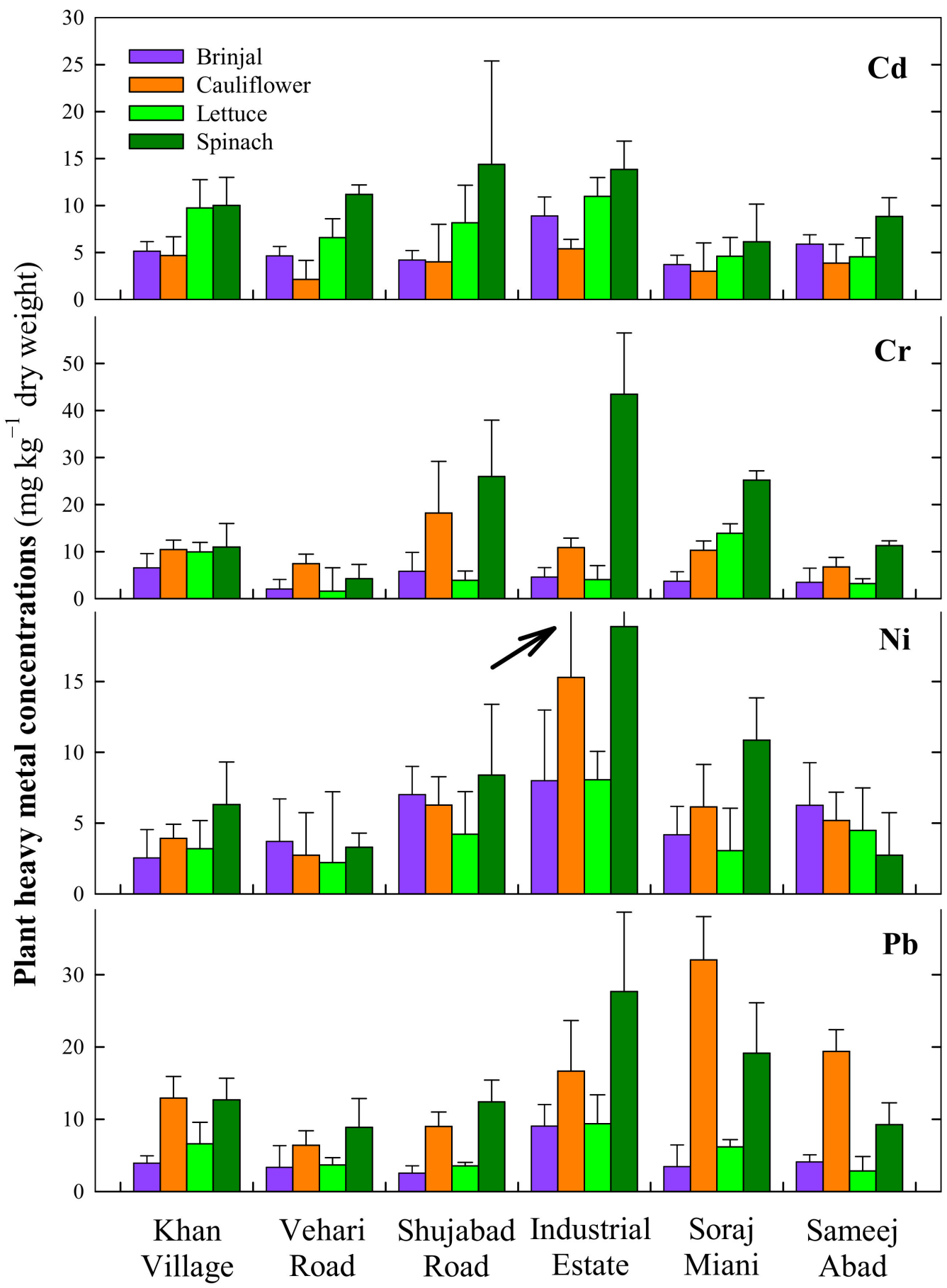

Figure 2. Heavy metal $\left(\mathrm{Cd}, \mathrm{Cr}, \mathrm{Ni}\right.$, and $\mathrm{Pb}$ ) concentrations ( $\mathrm{mg} \mathrm{kg}^{-1}$ dry weight) in brinjal (Solanum melogena) and spinach (Spinacia oleacea) harvested in April 2016, and lettuce (Lactuca sativa L.) and cauliflower (Brassica oleracea) harvested in December 2015 from the Khan village, Vehari road, Shujabad road, Industrial estate, Suraj miani and Sameej abad study sites. 


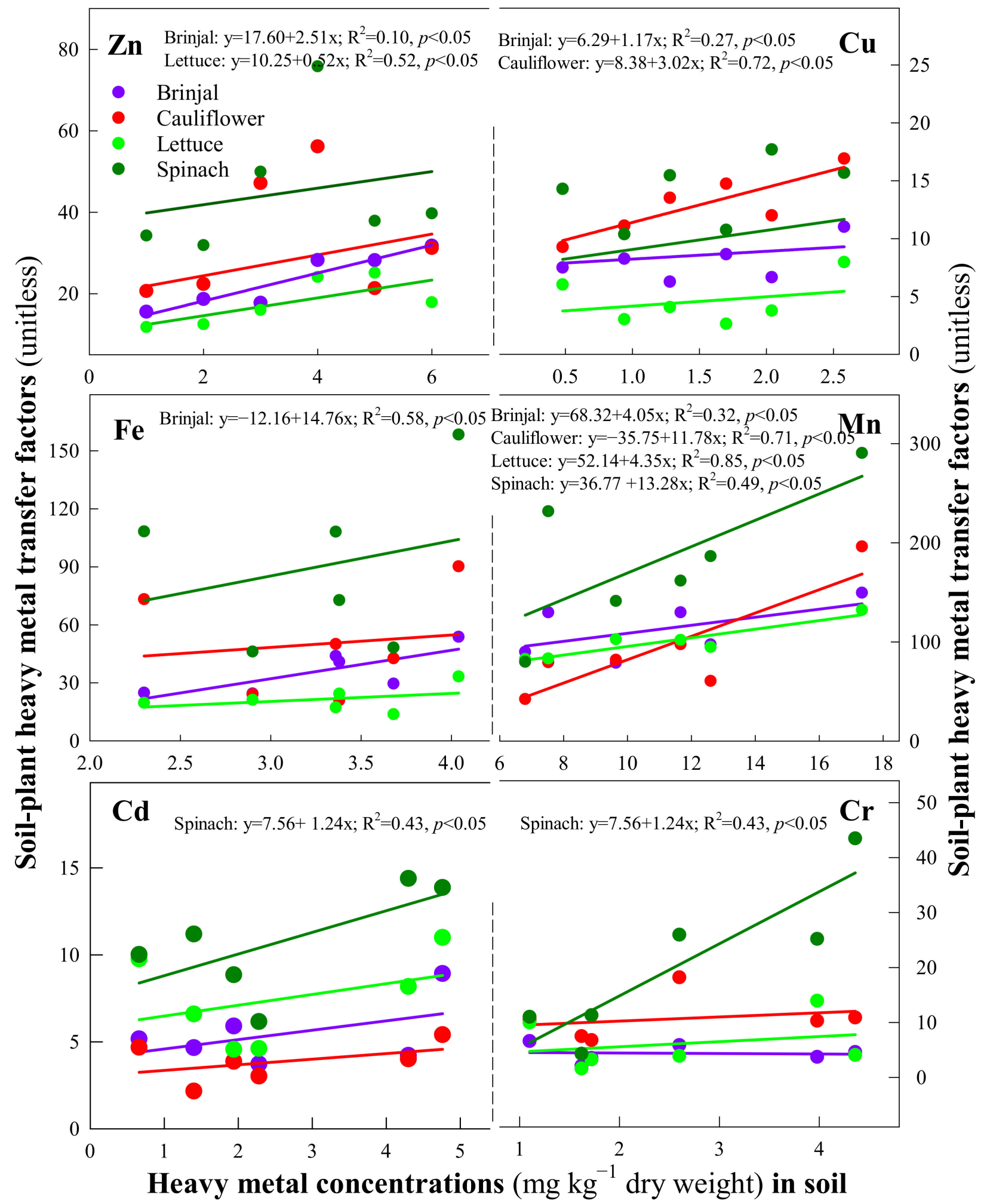

Figure 3. Relationships between the transfer factors (TF) of the vegetables (brinjal, cauliflower, lettuce, and spinach) and heavy metal ( $\mathrm{Zn}, \mathrm{Cu}, \mathrm{Fe}, \mathrm{Mn}, \mathrm{Cd}$, and $\mathrm{Cr}$ ) concentrations ( $\mathrm{mg} \mathrm{kg}^{-1}$ dry weight) in the respective soils of the Khan Village, Vehari road, Shujabad road, Industrial estate, Soraj miani, and Sameej abad study sites. A relationship is significant at $p<0.05$. Only significant relationships are retained to sustain the brevity of the manuscript. 


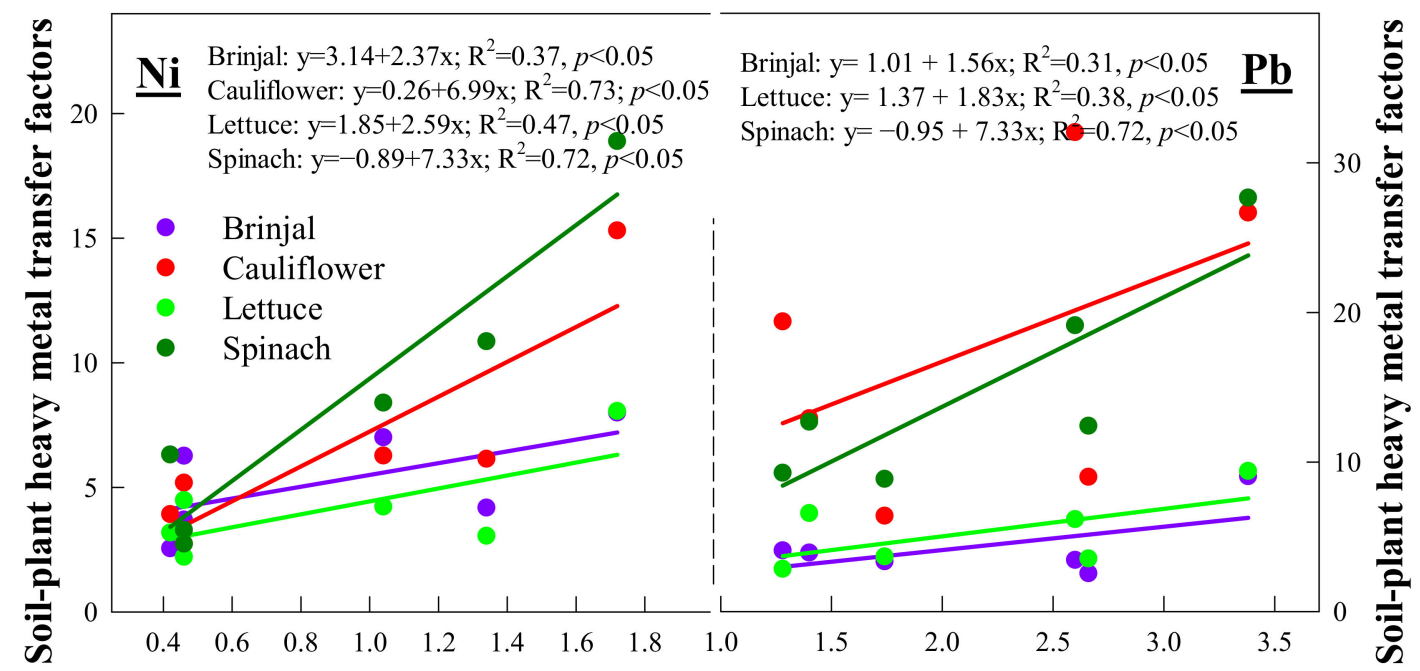

Heavy metal concentrations ( $\mathrm{mg} \mathrm{kg}^{-1}$ dry weight) in soil

Figure 4. Relationships between the transfer factors (TF) of the vegetables (brinjal, cauliflower, lettuce, and spinach) and heavy metal $\left(\mathrm{Ni}\right.$ and $\mathrm{Pb}$ ) concentrations $\left(\mathrm{mg} \mathrm{kg}^{-1}\right.$ dry weight) in the respective soils of the Khan Village, Vehari road, Shujabad road, Industrial estate, Soraj miani, and Sameej abad study sites. A relationship is significant at $p<0.05$. Only significant relationships are retained to sustain the brevity of the manuscript.

Table 2. Mean $( \pm S D)$ values (unitless) of the soil-plant transfer factors (vegetable leaf concentration/soil concentration) for all heavy metals across the study sites *.

\begin{tabular}{|c|c|c|c|c|c|c|c|c|}
\hline Site/Vegetable & $\mathrm{Zn}$ & $\mathrm{Cu}$ & $\mathrm{Fe}$ & Mn & $\mathrm{Cd}$ & $\mathrm{Cr}$ & $\mathbf{N i}$ & $\mathbf{P b}$ \\
\hline \multicolumn{9}{|l|}{ Khan Village } \\
\hline Brinjal & $8.6 \pm 3.9$ & $9.8 \pm 0.6$ & $13.3 \pm 0.9$ & $8.4 \pm 0.5$ & $7.8 \pm 0.4$ & $5.9 \pm 5.8$ & $6.0 \pm 0.1$ & $2.8 \pm 0.2$ \\
\hline Cauliflower & $11.4 \pm 1.7$ & $11.8 \pm 0.6$ & $6.2 \pm 0.9$ & $8.2 \pm 3.5$ & $7.0 \pm 5.3$ & $9.5 \pm 10.0$ & $9.3 \pm 0.5$ & $9.2 \pm 7.5$ \\
\hline Lettuce & $6.5 \pm 3.8$ & $3.2 \pm 0.4$ & $12.1 \pm 0.3$ & $7.2 \pm 3.2$ & $14.7 \pm 0.4$ & $9.0 \pm 10.0$ & $7.5 \pm 1.0$ & $4.6 \pm 0.3$ \\
\hline Spinach & $19.0 \pm 1.6$ & $11.0 \pm 0.1$ & $11.7 \pm 8.5$ & $15.9 \pm 1.0$ & $15.1 \pm 0.6$ & $10.0 \pm 8.8$ & $15.0 \pm 0.0$ & $9.0 \pm 0.1$ \\
\hline \multicolumn{9}{|l|}{ Vehari road } \\
\hline Brinjal & $11.2 \pm 2.6$ & $4.8 \pm 0.7$ & $8.1 \pm 0.9$ & $8.0 \pm 0.0$ & $3.3 \pm 1.2$ & $1.2 \pm 0.5$ & $8.0 \pm 0.1$ & $1.9 \pm 0.2$ \\
\hline Cauliflower & $13.4 \pm 4.6$ & $10.5 \pm 0.7$ & $8.5 \pm 0.6$ & $11.5 \pm 0.5$ & $1.5 \pm 0.6$ & $4.6 \pm 1.3$ & $5.9 \pm 0.7$ & $3.6 \pm 0.5$ \\
\hline Lettuce & $12.9 \pm 6.8$ & $3.1 \pm 0.4$ & $10.6 \pm 0.5$ & $3.7 \pm 0.5$ & $4.7 \pm 0.5$ & $0.9 \pm 0.0$ & $4.8 \pm 0.5$ & $2.1 \pm 0.2$ \\
\hline Spinach & $19.2 \pm 2.2$ & $12.0 \pm 0.1$ & $14.6 \pm 0.5$ & $13.1 \pm 0.1$ & $7.9 \pm 0.0$ & $2.6 \pm 0.5$ & $7.1 \pm 0.3$ & $5.0 \pm 0.2$ \\
\hline \multicolumn{9}{|l|}{ Shujabad road } \\
\hline Brinjal & $7.1 \pm 1.4$ & $5.0 \pm 0.2$ & $7.7 \pm 0.5$ & $12.0 \pm 4.2$ & $0.9 \pm 0.0$ & $2.2 \pm 1.3$ & $6.7 \pm 0.5$ & $0.9 \pm 0.1$ \\
\hline Cauliflower & $19.0 \pm 0.8$ & $8.6 \pm 0.8$ & $4.8 \pm 1.7$ & $6.1 \pm 0.9$ & $0.9 \pm 0.1$ & $7.0 \pm 4.8$ & $6.0 \pm 0.1$ & $3.3 \pm 3.1$ \\
\hline Lettuce & $6.4 \pm 1.2$ & $1.5 \pm 0.6$ & $7.5 \pm 0.5$ & $7.1 \pm 3.2$ & $1.9 \pm 0.2$ & $1.5 \pm 1.0$ & $4.0 \pm 0.1$ & $1.3 \pm 0.5$ \\
\hline Spinach & $20.1 \pm 5.5$ & $6.3 \pm 0.5$ & $14.7 \pm 6.9$ & $21.5 \pm 3.7$ & $3.3 \pm 0.5$ & $9.9 \pm 5.8$ & $8.0 \pm 0.1$ & $4.6 \pm 0.5$ \\
\hline \multicolumn{9}{|l|}{ Industrial estate } \\
\hline Brinjal & $9.0 \pm 0.1$ & $4.5 \pm 1.7$ & $8.6 \pm 0.5$ & $13.3 \pm 1.4$ & $1.8 \pm 0.3$ & $1.0 \pm 0.1$ & $4.6 \pm 0.5$ & $2.6 \pm 1.0$ \\
\hline Cauliflower & $14.4 \pm 0.5$ & $6.5 \pm 1.0$ & $11.3 \pm 3.3$ & $22.3 \pm 2.5$ & $1.1 \pm 0.3$ & $2.4 \pm 1.0$ & $8.8 \pm 0.2$ & $4.9 \pm 2.1$ \\
\hline Lettuce & $6.1 \pm 0.4$ & $3.0 \pm 2.1$ & $7.6 \pm 0.5$ & $8.21 \pm 0.5$ & $2.3 \pm 0.5$ & $0.9 \pm 0.1$ & $4.6 \pm 0.5$ & $2.7 \pm 1.5$ \\
\hline Spinach & $23.2 \pm 5.2$ & $6.0 \pm 0.2$ & $16.7 \pm 1.5$ & $39.2 \pm 1.4$ & $2.9 \pm 0.2$ & $9.9 \pm 5.8$ & $10.9 \pm 0.0$ & $8.1 \pm 0.6$ \\
\hline \multicolumn{9}{|l|}{ Soraj miani } \\
\hline$\overline{\text { Brinjal }}$ & $13.3 \pm 0.5$ & $3.2 \pm 1.0$ & $11.1 \pm 1.6$ & $13.0 \pm 0.7$ & $1.6 \pm 0.5$ & $0.9 \pm 0.1$ & $3.1 \pm 0.2$ & $1.3 \pm 0.5$ \\
\hline Cauliflower & $10.0 \pm 0.1$ & $5.8 \pm 0.6$ & $8.3 \pm 0.9$ & $14.9 \pm 0.8$ & $1.3 \pm 0.5$ & $2.5 \pm 0.5$ & $4.5 \pm 0.7$ & $12.2 \pm 1.4$ \\
\hline Lettuce & $11.8 \pm 4.0$ & $1.8 \pm 0.6$ & $8.7 \pm 1.0$ & $5.1 \pm 0.6$ & $2.0 \pm 0.0$ & $3.5 \pm 5.7$ & $2.2 \pm 0.5$ & $2.3 \pm 0.8$ \\
\hline Spinach & $17.8 \pm 0.6$ & $8.6 \pm 0.8$ & $13.8 \pm 5.9$ & $32.1 \pm 0.6$ & $2.7 \pm 0.5$ & $6.3 \pm 4.4$ & $8.0 \pm 0.2$ & $7.3 \pm 0.5$ \\
\hline \multicolumn{9}{|l|}{ Sameeja abad } \\
\hline Brinjal & $7.5 \pm 1.8$ & $18.7 \pm 1.5$ & $17.2 \pm 3.8$ & $10.7 \pm 0.9$ & $3.0 \pm 0.1$ & $2.0 \pm 0.1$ & $13.6 \pm 0.5$ & $3.1 \pm 0.5$ \\
\hline Cauliflower & $17.1 \pm 1.1$ & $19.3 \pm 0.9$ & $10.5 \pm 5.3$ & $31.8 \pm 2.1$ & $1.9 \pm 0.0$ & $3.9 \pm 0.1$ & $11.2 \pm 1.0$ & $15.1 \pm 0.6$ \\
\hline Lettuce & $9.8 \pm 1.6$ & $12.5 \pm 1.7$ & $11.0 \pm 2.0$ & $8.5 \pm 0.6$ & $2.3 \pm 0.5$ & $1.8 \pm 0.2$ & $9.7 \pm 0.5$ & $2.2 \pm 0.5$ \\
\hline Spinach & $21.8 \pm 2.5$ & $29.7 \pm 0.5$ & $30.7 \pm 4.9$ & $60.1 \pm 0.2$ & $4.5 \pm 0.5$ & $6.5 \pm 5.0$ & $5.9 \pm 0.1$ & $7.2 \pm 0.5$ \\
\hline
\end{tabular}

* Sites comparison: soil-plant transfer of Fe was significantly higher at the industrial estate site than that at the Khan Village site $\left(\mathrm{F}_{5,24}=2.51\right.$, $p=0.048, R^{2}=0.41$ ). The Ni transfer factor at the Industrial site was significantly higher than all sites except the Shujabad road site $\left(\mathrm{F}_{5,24}=5.51, p=0.003, \mathrm{R}^{2}=0.61\right)$. 
Table 3. Results of a two-way MANOVA of the soil-vegetable heavy metal transfer factor for six study sites in Multan, Pakistan.

\begin{tabular}{cccccccccc}
\hline Source & $\mathbf{d f}$ & $\mathbf{Z n}$ & $\mathbf{C u}$ & $\mathbf{F e}$ & $\mathbf{M n}$ & $\mathbf{C d}$ & $\mathbf{C r}$ & $\mathbf{N i}$ & $\mathbf{P b}$ \\
\hline Site & & & & & & & & & \\
$\mathbf{F}$ & 5,96 & 2.69 & 93.99 & 6.13 & 66.17 & 168.86 & 3.07 & 243.52 & 20.86 \\
$\boldsymbol{p}$ & 5,96 & $\mathbf{0 . 0 3}$ & $\mathbf{0 . 0 0}$ & $\mathbf{0 . 0 0}$ & $\mathbf{0 . 0 0}$ & $\mathbf{0 . 0 0}$ & $\mathbf{0 . 0 1}$ & $\mathbf{0 . 0 0}$ & $\mathbf{0 . 0 0}$ \\
$\begin{array}{c}\text { Vegetable } \\
\text { F }\end{array}$ & 5,96 & 52.50 & 131.85 & 13.59 & 257.04 & 108.95 & 17.64 & 213.05 & 90.90 \\
$\boldsymbol{p}$ & 5,96 & $\mathbf{0 . 0 0}$ & $\mathbf{0 . 0 0}$ & $\mathbf{0 . 0 0}$ & $\mathbf{0 . 0 0}$ & $\mathbf{0 . 0 0}$ & $\mathbf{0 . 0 0}$ & $\mathbf{0 . 0 0}$ & $\mathbf{0 . 0 0}$ \\
$\begin{array}{c}\text { Site } \times \text { Vegetable } \\
\text { F }\end{array}$ & 5,96 & 3.31 & 4.20 & 2.59 & 13.13 & 4.30 & 0.88 & 68.92 & 4.55 \\
$\boldsymbol{p}$ & 5,96 & $\mathbf{0 . 0 0}$ & $\mathbf{0 . 0 0}$ & $\mathbf{0 . 0 0}$ & $\mathbf{0 . 0 0}$ & $\mathbf{0 . 0 0}$ & 0.59 & $\mathbf{0 . 0 0}$ & $\mathbf{0 . 0 0}$ \\
$\mathbf{R}^{2}$ & 5,96 & 0.75 & 0.93 & 0.61 & 0.95 & 0.95 & 0.53 & 0.98 & 0.86 \\
\hline
\end{tabular}

Bold values are significant at the $=0.05$ level. $\mathrm{R}^{2}$ shows the relationship between the soil and plant heavy metal concentrations.

\section{Discussion}

In this study, the phytoextractions of soil $\mathrm{Zn}, \mathrm{Cu}, \mathrm{Fe}, \mathrm{Mn}, \mathrm{Cd}, \mathrm{Cr}, \mathrm{Ni}$, and $\mathrm{Pb}$ heavy metals by the four vegetables (brinjal, cauliflower, lettuce, and spinach), grown on six sites equally divided into sandy loam and clay loam soils, and where each soil was irrigated with three types of water-normal, sewage, and normal + sewage-were measured. Since comparing the phytoextraction values of the vegetables grown on different textured soils irrigated with different types of waters would not be satisfying, we additionally compared the vegetable transfer factor (VTF; Cui et al. [20]), which is equal to the heavy metal concentration in the vegetable divided by the heavy metal concentration in the soil. The VTF minimizes biases in comparative phytoextraction values owing to differences in heavy metal concentrations among the soil textures as well as the irrigation waters used in the study.

\subsection{Effect of Site/Water on Phytoextraction of Heavy Metals}

In this study, heavy metal phytoextraction of all heavy metals was the highest at the Industrial estate study site, which had a clay loam texture and was being irrigated with the sewage water. The overall phytoextractions of heavy metals by the four vegetables at this site were significantly higher than those at the Khan Village and Sameej abad sites, which had sandy loam and clay loam textures, respectively, and were being irrigated with normal water. Moreover, Shujabad road site (sandy loam) vegetables had also clearly higher phytoextractions than those of the crops at the sites being irrigated with normal water. These results are in line with that of Yargholi [36], who also reported significant increases in heavy metal concentrations in soil (or VTF) in response to irrigation with sewage water of high heavy metal concentrations. The toxic concentration of the heavy metals or other micro/nutrients in the irrigation water has frequently been reported, for example, $[37,38]$ to directly concentrate in the plant roots/shoots/leaves, which food may put the health and life of animals and humans in jeopardy.

The highest phytoextraction by the industrial site vegetables was likely due to the greatest soil concentrations of the respective heavy metals owing to continuous use of sewage water at this heavy soil texture site. It also reveals that the soil particle exchange sites of this heavy texture site tend to be fully occupied and are transferring the surplus to the crops, resulting in high VTF factors. A similar phenomenon is also shown by the Shujabad road site; however, the extent of the transfer of heavy metals to the vegetables was much lower due to the light texture nature of the soil, which may, for example, accumulate or supply lesser heavy metals to the plant parts [39].

Overall phytoextraction of heavy metals by vegetable crops showed that spinach had the highest phytoextraction of all the heavy metals followed by cauliflower and lettuce, while brinjal had the lowest phytoextraction of heavy metals, as was also found by Sharma et al. $[17,18]$. The phyto uptake capability of the spinach crop we found is comparable to 
the findings of $\mathrm{Ng}$ et al. [40]. The highest heavy metal phytoextraction of spinach could be attributed to its leafy structure, short stature and growth cycle, and the fastest metabolism, which can uptake toxic compounds or heavy metals in toxic quantities and transform or mineralize them to simpler compounds, which can be assimilated or accumulated for the long term. There was a site * vegetable interaction for spinach at the Industrial estate site, which has a heavy soil texture irrigated with sewage water, again supporting our findings on the individual effects of site and vegetable on the phytoextraction of the heavy metals, and also support the findings of Zia et al. [34], except they used phytoextraction enhancing chemicals.

\subsection{Effect of Site/Water on Vegetable Transfer Factor}

In contrast to the phytoextraction values, the VTF values were found to be the highest at the Sameeja abad site of heavy texture and irrigated with a mix of normal and sewage waters (the exact ratio of the mix is not reported since it kept changing). It was found that the crops had visually much higher coverages and biomasses than those at the other experimental sites. Vegetation may attain maximum coverage and biomass when supplied with exponentially dissolved organic carbon and salts or ions in soils [41]. Therefore, a higher VTF at this site could be attributed to greater uptake of heavy metals (relative to its soil concentrations) along with essential nutrients in contrast to the Industrial estate, which had greater concentrations of heavy metals in both the soil and vegetable crop and the VTF was low due to the much higher soil heavy metal concentrations than those at the Sameeja abad site. The findings of Cui et al. [20] corroborate our explanation of the higher VTFs of vegetables due to lower soil heavy metal concentrations.

Interestingly, spinach had overall the highest VTF values of all the heavy metals, similar to its corresponding phytoextraction values. Additionally, the VTF values of cauliflower, lettuce, and brinjal were also in the order similar to those of the phytoextraction values of these vegetables. These findings complement our results on the phytoextraction capacities of the four vegetable crops used in this study.

\section{Conclusions}

Vegetables, one of the most important foods for humans, are also efficient phytoextractants of heavy metals in soils. When grown on heavy or light-textured soils irrigated with sewage water, vegetable crops phytoextracted the heavy metals to highly toxic levels. Spinach was the most efficient phytoextractant followed by cauliflower and lettuce, while brinjal was the least efficient of all. We suggest that soils, when irrigated with sewage water having excessive concentrations of the studied heavy metals, may transfer these metals in toxic amounts to vegetable crop plants.

Author Contributions: Conceptualization, I.A., S.S. and S.A.M.; methodology, I.A., A.-u.R.; software, T.M.M.; validation, I.A., S.S. and S.A.M.; formal analysis, T.M.M.; investigation, I.A., S.S., A.-u.R. and S.A.M.; resources, S.S.; data curation, I.A.; writing—original draft preparation, I.A.; writing-review and editing, S.S., A.-u.R., and T.M.M.; visualization, I.A., and A.-u.R.; supervision, S.S., T.M.M.; project administration, S.A.M., and S.S.; funding acquisition, S.S. All authors have read and agreed to the published version of the manuscript.

Funding: This research received funding from the Bahauddin Zakariya University (GR-2021-197), Multan, and Muhammad Nawaz Sharif University of Agriculture (GR-2021-Mul-427), Multan.

Institutional Review Board Statement: Not applicable.

Informed Consent Statement: Not applicable.

Data Availability Statement: All data analyzed in this study are available from the corresponding author upon request.

Conflicts of Interest: The authors declare no conflict of interest. 


\section{References}

1. IPCC. Intergovernmental Panel on Climate Change, in Climate change 2014: Impacts, Adaptation, and Vulnerability: Working Group II Contribution to the Fifth Assessment Report of the Intergovernmental Panel on Climate Change. 2014. Available online: https: / / www.ipcc.ch/report/ar5/wg2/ (accessed on 18 June 2021).

2. Chaudhry, Q.U.Z. Climate Change Profile of Pakistan; Asian Development Bank: Mandaluyong, Philippines, 2017.

3. Krishnan, R.; Shrestha, A.B.; Ren, G.; Rajbhandari, R.; Saeed, S.; Sanjay, J.; Syed, M.A.; Vellore, R.; Xu, Y.; You, Q. Unravelling climate change in the Hindu Kush Himalaya: Rapid warming in the mountains and increasing extremes. In The Hindu Kush Himalaya Assessment; Springer: Berlin/Heidelberg, Germany, 2019; pp. 57-97.

4. Ali, S.; Kiani, R.S.; Reboita, M.S.; Dan, L.; Eum, H.I.; Cho, J.; Dairaku, K.; Khan, F.; Shreshta, M.L. Identifying hotspots cities vulnerable to climate change in Pakistan under CMIP5 climate projections. Int. J. Climatol. 2021, 41, 559-581. [CrossRef]

5. Barros, V.; Field, C.; Dokke, D.; Mastrandrea, M.; Mach, K.; Bilir, T.; Chatterjee, M.; Ebi, K.; Estrada, Y.; Genova, R. Climate Change 2014: Impacts, Adaptation, and Vulnerability. Part B: Regional Aspects; Contribution of Working Group II to the Fifth Assessment Report of the Intergovernmental Panel on Climate Change; Cambridge University Press: New York, NY, USA, 2014.

6. Asif, M. Climatic Change, Irrigation Water Crisis and Food Security in Pakistan; Uppsala University: Uppsala, Sweden, 2013.

7. Munir, T.M.; Perkins, M.; Kaing, E.; Strack, M. Carbon dioxide flux and net primary production of a boreal treed bog: Responses to warming and water-table-lowering simulations of climate change. Biogeosciences 2015, 12, 1091-1111. [CrossRef]

8. Lone, M. Comparison of blended and cyclic use of water for agriculture. In Final Report University Grant Commission, Islamabad. Pakistan; University Grants Commission: Islamabad, Pakistan, 1995.

9. Silva, H.F.; Silva, N.F.; Oliveira, C.M.; Matos, M.J. Heavy Metals Contamination of Urban Soils-A Decade Study in the City of Lisbon, Portugal. Soil Syst. 2021, 5, 27. [CrossRef]

10. Mahmood, S. Waste water irrigation: Issues and constraints for sustainable irrigated agriculture. J. Ital. Agron. 2006, 3, 12-15.

11. Drechsel, P.; Raschid-Sally, L.; Williams, S.; Weale, J. Recycling Realities: Managing health risks to make wastewater an asset. Water Policy Brief. 2006, 17, 1-7.

12. Cooper, R.C. Public health concerns in wastewater reuse. Water Sci. Technol. 1991, 24, 55-65. [CrossRef]

13. Mara, D.D.; Cairncross, S. Guidelines for the Safe Use of Wastewater and Excreta in Agriculture and Aquaculture; World Health Organization: London, UK, 1989.

14. Curci, M.; Lavecchia, A.; Cucci, G.; Lacolla, G.; De Corato, U.; Crecchio, C. Short-Term Effects of Sewage Sludge Compost Amendment on Semiarid Soil. Soil Syst. 2020, 4, 48. [CrossRef]

15. Thakur, I.S. Environmental Biotechnology: Basic Concepts and Applications; IK International: Delhi, India, 2011.

16. Matzen, S.; Fakra, S.; Nico, P.; Pallud, C. Pteris vittata Arsenic Accumulation Only Partially Explains Soil Arsenic Depletion during Field-Scale Phytoextraction. Soil Syst. 2020, 4, 71. [CrossRef]

17. Sharma, R.; Agrawal, M.; Marshall, F. Heavy metal contamination in vegetables grown in wastewater irrigated areas of Varanasi, India. Bull. Environ. Contam. Toxicol. 2006, 77, 312-318. [CrossRef]

18. Sharma, R.K.; Agrawal, M.; Marshall, F. Heavy metal contamination of soil and vegetables in suburban areas of Varanasi, India. Ecotoxicol. Environ. Saf. 2007, 66, 258-266. [CrossRef]

19. Ilic, Z.; Filipovic-Trajkovic, R.; Jablanovic, M. Transfer factor (coefficient) soil/plant as indicator concentration of heavy metals content in different vegetable species. Contemp. Agric. 2001, 50, 41-44.

20. Cui, Y.-J.; Zhu, Y.-G.; Zhai, R.-H.; Chen, D.-Y.; Huang, Y.-Z.; Qiu, Y.; Liang, J.-Z. Transfer of metals from soil to vegetables in an area near a smelter in Nanning, China. Environ. Int. 2004, 30, 785-791. [CrossRef] [PubMed]

21. Rattan, R.; Datta, S.; Chhonkar, P.; Suribabu, K.; Singh, A. Long-term impact of irrigation with sewage effluents on heavy metal content in soils, crops and groundwater-A case study. Agric. Ecosyst. Environ. 2005, 109, 310-322. [CrossRef]

22. Vassilev, A.; Yordanov, I. Reductive analysis of factors limiting growth of cadmium-treated plants: A review. Bulg. J. Plant Physiol. 1997, 23, 114-133.

23. Lone, M.I.; Saleem, S.; Mahmood, T.; Saifullah, K.; Hussain, G. Heavy metal contents of vegetables irrigated by Sewage/Tubewell water. Int. J. Agric. Biol. 2003, 5, 533-535.

24. Moral, R.; Cortés, A.; Gomez, I.; Mataix-Beneyto, J. Assessing changes in Cd phytoavailability to tomato in amended calcareous soils. Bioresour. Technol. 2002, 85, 63-68. [CrossRef]

25. Das, P.; Samantaray, S.; Rout, G. Studies on cadmium toxicity in plants: A review. Environ. Pollut. 1997, 98, 29-36. [CrossRef]

26. Mir, I.R.; Rather, B.A.; Masood, A.; Majid, A.; Sehar, Z.; Anjum, N.A.; Sofo, A.; D’Ippolito, I.; Khan, N.A. Soil Sulfur Sources Differentially Enhance Cadmium Tolerance in Indian Mustard (Brassica juncea L.). Soil Syst. 2021, 5, 29. [CrossRef]

27. Shanker, A.K.; Cervantes, C.; Loza-Tavera, H.; Avudainayagam, S. Chromium toxicity in plants. Environ. Int. 2005, 31, 739-753. [CrossRef]

28. Nolan, K.R. Copper toxicity syndrome. J. Orthomol. Psychiatry 1983, 12, 270-282.

29. Di Toppi, L.S.; Gabbrielli, R. Response to cadmium in higher plants. Environ. Exp. Bot. 1999, 41, 105-130. [CrossRef]

30. Rahman, M.A.; Rahman, M.M.; Reichman, S.M.; Lim, R.P.; Naidu, R. Heavy metals in Australian grown and imported rice and vegetables on sale in Australia: Health hazard. Ecotoxicol. Environ. Saf. 2014, 100, 53-60. [CrossRef]

31. Chaney, R.L.; Malik, M.; Li, Y.M.; Brown, S.L.; Brewer, E.P.; Angle, J.S.; Baker, A.J. Phytoremediation of soil metals. Curr. Opin. Biotechnol. 1997, 8, 279-284. [CrossRef] 
32. Salt, D.E.; Blaylock, M.; Kumar, N.P.; Dushenkov, V.; Ensley, B.D.; Chet, I.; Raskin, I. Phytoremediation: A novel strategy for the removal of toxic metals from the environment using plants. Nat. Biotechnol. 1995, 13, 468-474. [CrossRef] [PubMed]

33. Richards, L. Diagnosis and improving of saline and alkaline soils. US, Salinity Laboratory Staff. Agric. Handb. 1954, 46, 290.

34. Zia, M.H.; Meers, E.; Ghafoor, A.; Murtaza, G.; Sabir, M.; Zia-ur-Rehman, M.; Tack, F. Chemically enhanced phytoextraction of Pb by wheat in texturally different soils. Chemosphere 2010, 79, 652-658.

35. APHA. Standard methods for the examination of water and wastewater. Water Environ. Fed. 2005, 21, $258-259$.

36. Yargholi, B. Investigation of the Firozabad Wastewater Quality-Quantity Variation for Agricultural Use; Final Report; Iranian Agricultural Engineering Research Institute: Tehran, Iran, 2007.

37. Ali, H.; Khan, E.; Ilahi, I. Environmental chemistry and ecotoxicology of hazardous heavy metals: Environmental persistence, toxicity, and bioaccumulation. J. Chem. 2019, 2019, 6730305. [CrossRef]

38. Iqbal, Z.; Abbas, F.; Ibrahim, M.; Qureshi, T.I.; Gul, M.; Mahmood, A. Human health risk assessment of heavy metals in raw milk of buffalo feeding at wastewater-irrigated agricultural farms in Pakistan. Environ. Sci. Pollut. Res. 2020, 27, 29567-29579. [CrossRef]

39. Liang, J.; Chen, C.; Song, X.; Han, Y.; Liang, Z. Assessment of heavy metal pollution in soil and plants from Dunhua sewage irrigation area. Int. J. Electrochem. Sci. 2011, 6, 5314-5324.

40. Ng, C.C.; Rahman, M.M.; Boyce, A.N.; Abas, M.R. Heavy metals phyto-assessment in commonly grown vegetables: Water spinach (I. aquatica) and okra (A. esculentus). SpringerPlus 2016, 5, 1-9. [CrossRef] [PubMed]

41. Strack, M.; Munir, T.M.; Khadka, B. Shrub abundance contributes to shifts in dissolved organic carbon concentration and chemistry in a continental bog exposed to drainage and warming. Ecohydrology 2019, 12, e2100. [CrossRef] 